\title{
GROWTH AND SPORULATION OF Metarhizium flavoviride var. Flavoviride on CULTURE MEDIA AND LIGHTING REGIMES
}

\author{
Sideney Becker Onofre" ${ }^{1 *}$; Cindia Mara Miniuk'; Neiva Monteiro de Barros²; João Lúcio \\ Azevedo $2,3,4$ \\ ${ }^{1}$ Depto. de Ciências e Engenharia - Curso de Agronomia - Centro Federal de Educação Tecnológica do Paraná, \\ Unidade de Ensino de Pato Branco, C.P. 570 - CEP: 85503-390 - Pato Branco, PR. \\ ${ }^{2}$ Depto. de Ciências Biológicas e Instituto de Biotecnologia da Universidade de Caxias do Sul, C.P. 152 - \\ CEP: 95001-970 - Caxias do Sul, RS. \\ ${ }^{3}$ Depto. de Genética - USP/ESALQ, C.P. 83 - CEP: 13416-900 - Piracicaba, SP. \\ ${ }^{4}$ Núcleo Integrado de Biotecnologia, Universidade de Mogi das Cruzes - UMC - CEP: 08780-911 - Mogi das Cruzes, SP. \\ ${ }^{*}$ Corresponding author <becker@qualinet.com.br>
}

ABSTRACT: Entomopathogenic fungi from the genus Metarhizium are largely used for the biological control of agricultural pests by conidia spreading on the field. Although conidia production is well studied in M. anisopliae, only few research studies were done in $M$. flavoviride. The present work was carried out alming to evaluate the Mycelial growth and sporulation of the entomopathogenic fungus Metarhizium flavoviride var. flavoviride growing at $27 \pm 2^{\circ} \mathrm{C}$ on Potato-dextrose-agar (PDA), Czapek-agar (CZP) and a complete agar medium (CM) under three lighting regimes, (continuous illumination, light/dark cycle and an black light/dark cycle) were investigated. A completely randomized $3 \times 3$ (culture media $\times$ lighting regime) factorial design with four replicates was used. The best mycelial growth and sporulation occurred on the PDA and CM media under continuous illumination $(P \leq 0,05)$.

Key words: Metarhizium flavoviride, mycelial growth, culture media, lighting regimes

\section{CRESCIMENTO E ESPORULAÇÃO DE Metarhizium flavoviride var. Flavoviride EM MEIOS DE CULTURA E REGIMES DE LUZ}

\begin{abstract}
RESUMO: Fungos entomopatogênicos do genêro Metarhizium são empregados no controle biológico de pragas agrícolas por meio da dispersão de seus conídios no campo. Embora a produção de conídios em $M$. anisopliae esteja bem estudada, poucas pesquisas a respeito existem na espécie $M$. flavoviride. O presente trabalho foi realizado para avaliar o efeito de três meios de cultura, batata-dextrose-ágar (BDA), Czapek-ágar (CZP) e meio completo (MC), e três regimes de luminosidade, claro contínuo, alternância com luz do dia/ escuro e luz negra/escuro, sobre o crescimento miceliano e esporulação do fungo entomopatogênico Metarhizium flavoviride var. flavoviride. O experimento foi realizado em câmara de incubação à temperatura de $27 \pm 2^{\circ} \mathrm{C}$. Empregou-se um delineamento experimental inteiramente casualizado, em arranjo fatorial $3^{\circ} \mathrm{C}$ 3 (meios de cultura e regime de luminosidade) com quatro repetições. As melhores condições para 0 crescimento miceliano e esporulação foram conseguidas tanto no meio de cultura BDA como no MC quando combinados com o regime claro contínuo $(P \leq 0,05)$.
\end{abstract}

Palavras-chave: Metarhizium flavoviride, crescimento, meios de cultivo, luminosidade

\section{INTRODUCTION}

Insect pathogenic fungi are widely used for biological control. According to Alves (1998), nearly $80 \%$ of insect diseases have fungi as ethiological agents. These fungi belong to approximate 90 genera and more than 700 species. Among them, the genus Metarhizium has stood out due to presenting good efficiency in controlling various agricultural pests. Tulloch (1976) distinguishes two species, $M$. anisopliae and $M$. flavoviride, each one with two varieties. M. anisopliae var. anisopliae is the most studied one, with several isolates appropriate for biological control. Some isolates from this fungus have already been selected and used in Brazil for biological control (Sosa-Gomes \& Alves, 1983). The specie $M$. anisopliae has been submitted to intense genetic studies, having its parasexual cycle already described (Messias \& Azevedo, 1980). Several mutants are known, making it suitable for genetic analyses (KavaCordeiro et al., 1995). In fact, thanks to these studies, it was possible to demonstrate the existence of a recombination alternative called parameiosis (Bagalhi et al., 1991) in this fungus, which has allowed the establishment of genetic improvement programs. The $M$. anisopliae genetic improvement has already been the object of several reviews (Azevedo et al., 1987; Azevedo $1998 a, b)$. The standardization of factors that allowed the species appropriate development in laboratory conditions was important in order to apply genetics and improvement programs to it. Factors such as 
temperature, lighting conditions, and synthetic and complex culture media, among others, have been studied (Alves \& Moraes, 1979; Alves et al., 1979; Alves et al., 1980; Vale, 1983; Frigo \& Azevedo, 1986). These studies have guaranteed adequate sporulation and growth for the use of genetic techniques of analyses.

M. flavoviride has also been used for insect biological control, especially of Orthoptera, Homoptera and Coleoptera. In Brazil, it has been isolated from Shistocerca pallens (Orthoptera: Acrididae) being tested against grasshoppers (Vicentini \& Magalhães, 1996; Magalhães, 1997) and ticks (Onofre, 1998; Onofre et al., 2001). Although studies on the influence of some factors on the fungus sporulation (Magalhães \& Frazão, 1996) have been carried out, the species is still very poorly studied, and its parasexual cycle, if existent, has not been described yet. Thus, for M. flavoviride, as was done for $M$. anisopliae, it is necessary to study the most appropriate conditions for the species cultivation, in order to allow better growth conditions, sporulation and, consequently, production of mutants for later verification of whether recombination systems exist or not. This would support the setting up of genetic improvement programs for M. flavoviride.

Therefore, the present work aimed at studying the influence of three culture media and three lighting regimes on mycelial growth and conidia production of the entomopathogenic fungus $M$. flavoviride var. flavoviride with the intention of subsidizing later genetic studies aimed at producing nutritional and morphological deficient mutants and recombination systems for genetic improvement programs use.

\section{MATERIAL AND METHODS}

Fungal Strain: The M. flavoviride var flavoviride strain CG-291 USDA-ARS (ARSEF 324) isolated from Austracnis guttulosa (Orthoptera: Acrididae), Queensland, Australia, was provide by EMBRAPA/CENARGEN ("Empresa Brasileira de Pesquisas Agropecuárias/Centro de Recursos Genéticos e Biotecnologia") Brasilia - Distrito Federal, Brazil.

Lighting regimes: The lighting regimes tested were as follows: light (daylight fluorescent lamps, Phillips, 40-watt) and alternating illumination, light/dark cycle and an black light/dark cycle, both in a 12-hour photophase.

Culture media: Potato-dextrose-agar medium, PDA - Difco ${ }^{\circledR}$ (potato $=200 \mathrm{~g}$; dextrose $=15 \mathrm{~g}$; agar $=17 \mathrm{~g}$; distilled water $=1,000 \mathrm{~mL}$ ). Czapek-agar medium, CZP $\left(\mathrm{NaNO}_{3}=3 \mathrm{~g} ; \mathrm{K}_{2} \mathrm{HPO}_{4}=1 \mathrm{~g} ; \mathrm{MgSO}_{4} \cdot 7 \mathrm{H}_{2} \mathrm{O}=0.5 \mathrm{~g} ; \mathrm{KCL}=\right.$ $0.5 \mathrm{~g} ; \mathrm{FeSO}_{4}=0.01 \mathrm{~g}$; sacarose $=30 \mathrm{~g}$; agar $\left(\right.$ Merck $\left.^{\circledR}\right)=$ $15 \mathrm{~g}$; distilled water $=1,000 \mathrm{~mL}$ ). Complete agar medium, CM (Pontecorvo et al., 1953, modified by Azevedo \& Costa, 1973) $\quad \mathrm{NaNO}_{3}=6.0 \quad \mathrm{~g} ; \mathrm{K}_{2} \mathrm{HPO}_{4}=1.5 \mathrm{~g}$; $\mathrm{MgSO}_{4} \cdot 7 \mathrm{H}_{2} \mathrm{O}=0.5 \mathrm{~g} ; \mathrm{KCL}=0.5 \mathrm{~g} ; \mathrm{FeSO}_{4}=0.001 \mathrm{~g}$;
$\mathrm{ZnSO}_{4}=0.001 ;$ glicose $=10.0 \mathrm{~g}$; east extract $=0.5 \mathrm{~g}$; peptone $=2.0 \mathrm{~g}$; hydrolyzed casein $=1.5 \mathrm{~g}$; vitamins solution $\left(100 \mathrm{mg} \mathrm{L}^{-1}\right.$ nicotinic acid; $10 \mathrm{mg} \mathrm{L}^{-1}$ p-aminobenzoic acid; $50 \mathrm{mg} \mathrm{L}^{-1}$ tiamine; $50 \mathrm{mg} \mathrm{L}^{-1}$ pyridoxine; $0,02 \mathrm{mg} \mathrm{L}^{-1}$ biotin; $100 \mathrm{mg} \mathrm{L}^{-1}$ riboflavin, distilled water to $100 \mathrm{mg} \mathrm{L}^{-1}$ ) $=1.0 \mathrm{~mL}$; agar $=15.0 \mathrm{~g}$; distilled water $=1,000 \mathrm{~mL}$. For all media $\mathrm{pH}$ was adjusted to 6.8 .

Mycelial growth evaluation and conidia production: The original $M$. flavoviride var. flavoviride culture was kept on PDA under a light/dark regime (12 hours in darkness and 12 hours in the light) for 96 hours at $27 \pm 2^{\circ} \mathrm{C}$. Then, five-centimeter diameter disks were taken from the active growth region of the fungal colony, and transferred to the center of ten - centimeter diameter petri dishes containing $20 \mathrm{~mL}$ of the culture media to be tested. The incubation was conducted according to the lighting regime defined by the treatment, at $27 \pm 2^{\circ} \mathrm{C}$.

The luminosity employed in the continuous illumination and light/dark cycle treatments was achieved by means of a set of 40-watt "daylight" fluorescent lamps, Phillips trademark, placed $40 \mathrm{~cm}$ far from the dishes. For the light/dark cycle regime with ultraviolet light, a 40-watt black light fluorescent source, Phillips trademark, at 40 $\mathrm{cm}$ distant from the dishes was used. The 12-hour complete darkness phase was achieved by covering the dishes completely with black paper sheets.

In order to estimate the mycelial growth, the diameter of the colonies was measured at 12-hour intervals. The conidia amount produced was evaluated after seven days, when the mycelial growth in whichever treatment reached the full diameter of the petri dishes. The sporulation data were obtained by conidia counting in a Neubauer chamber, after preparation of a standard conidial suspension. This was prepared according to the methodology described by Alves et al. (1980), which consists in the total scraping of the conidia from the dishes with the different culture media and addition of 100 $\mathrm{mL}$ distilled water as well as $0.1 \mathrm{~mL}$ Tween $80(0.1 \%$ $\mathrm{v} / \mathrm{v}$ ) The suspensions were stirred by magnetic stirrer for 5 minutes previously to the counting in Neubauer chamber under an optical microscope.

\section{RESULTS AND DISCUSSION}

Data from mycelial growth obtained is shown in TABLE 1. The analysis of variance $(P \leq 0.05)$ showed significant effect of the culture media and lighting regime on the fungus growth. The different media, regardless of lighting, PDA and CM were the ones that allowed better fungal radial growth. Considering the lighting regime effect, regardless of culture medium, a greater mycelial growth was verified under the continuous illumination light cycle.

The results may be explained, to a certain extent, by the existence of growth promoting factors present in 
TABLE 1 - Influence of culture medium and lighting regime on the mycelial growth of Metarhizium flavoviride var. flavoviride.

\begin{tabular}{llcc}
\hline \multirow{2}{*}{ Lighting regime } & \multicolumn{3}{c}{ Colony diameter $(\mathrm{mm})^{1}$} \\
\cline { 2 - 4 } & \multicolumn{3}{c}{ Culture medium } \\
\cline { 2 - 4 } & PDA & CM & CZP \\
\hline $\begin{array}{l}\text { Continuous light } \\
\begin{array}{l}\text { Alternating ultraviolet } \\
\text { light/dark cycle }\end{array}\end{array}$ & 84,7 aA & 74,8 aB & $41,1 \mathrm{aC}$ \\
$\begin{array}{l}\text { Alternating light/dark } \\
\text { cycle }\end{array}$ & $69,8 \mathrm{bA}$ & $72,5 \mathrm{aA}$ & $39,6 \mathrm{aB}$ \\
\hline
\end{tabular}

${ }^{1}$ Average of four replications/treatment. Averagens followed by the same small letter (vertical) and capital letter (horizontal) do not differ among them by Tukey test at $5 \%$.

the different culture media employed. These factors may be responsible for the maintenance of a nutritiously better-balanced growth substrate when compared to a relatively poor mixture, provided by CZP, in which all constituents, but sucrose and agar, are minerals. Similar considerations were drawn by Lilly \& Barnett (1951), Frigo \& Azevedo (1986), Ingleby et al. (1998), Cox \& Thomas (1999), Akpomedaye \& Ejechi (1999), when they stated that for many fungi, natural or semi-synthetic media provide certain substances which can meet the nutritious growth demands in a more efficient way than synthetic media.

On the other hand, the continuous illumination lighting regime associated to PDA medium was the treatment which gave the best results. Under this concept, Lilly \& Barnett (1951) and Frigo \& Azevedo (1986) stated that one of the main functions of the vegetative phase is the storage of energy to be conveniently used in the reproductive phase.

Considering the light factor, Cochrane (1997) and Inglis et al. (1999) quote that the visible light presents stimulating effect on reproduction, not only triggering the reproductive primordia maturation, but also increasing the number of such structures in absolute values.

PDA and CM were the media which showed to be most promising to sporulation, especially when the culture in PDA was submitted to a continuous light regime (TABLE 2).

Considering only the light effect, Griffin (1994) points out that some fungi may even start the sporulation process in the absence of light; however, this factor turns to be uppermost in the final phase of the process. This fact, in a way, is in accordance with the data found in this work, where the continuous illumination condition stimulated higher sporulation indexes.

PDA and CM were the best substrates for micelial growth and sporulation of the entomopathogenic fungus Metarhizium flavoviride var. flavoviride and that the best lighting regime for a greater micelial growth and sporulation was the continuous light cycle, especially when the substrate used was PDA.
TABLE 2 - Influence of culture medium and lighting regime on the sporulation of Metarhizium flavoviride var. flavoviride.

\begin{tabular}{lccc}
\hline \multirow{2}{*}{ Lighting regime } & \multicolumn{3}{c}{ Sporulation (conidia/mL x 106) } \\
\cline { 2 - 4 } & \multicolumn{3}{c}{ Culture medium } \\
\cline { 2 - 4 } & PDA & CM & CZP \\
\hline $\begin{array}{l}\text { Continuo us light } \\
\begin{array}{l}\text { Alternating ultraviolet } \\
\text { light/dark cycle }\end{array}\end{array}$ & $1.0 \mathrm{aA}$ & $3.4 \mathrm{aB}$ & $2.9 \mathrm{aB}$ \\
$\begin{array}{l}\text { Alternating light/dark } \\
\text { cycle }\end{array}$ & $2.0 \mathrm{bA}$ & $2.8 \mathrm{abA}$ & $1.7 \mathrm{aB}$ \\
\hline
\end{tabular}

${ }^{1}$ Average of four replications/treatment. Averagens followed by the same small letter (vertical) and capital letter (horizontal) do not differ among them by Tukey test at $5 \%$.

\section{ACKNOWLEDGMENTS}

To "Empresa Brasileira de Pesquisas Agropecuárias, Centro Nacional de Recursos Genéticos e Biotecnologia - EMBRAPA/CENARGEN" and CNPq for the financial support.

\section{REFERENCES}

AKPOMEDAYE, D.E.; EJECHI, B.O. The hurdle effect of milk heat and two tropical spice extracts on the growth of three fungi in fruit juices. Food Research, v.31, p.339-341, 1999.

ALVES, S. B. Controle microbiano de insetos. Piracicaba: FEALQ, 1998. 1163p.

ALVES, S.B.; MILANEZ, J.M.; KASTEN JR., P. Influência do fotoperíodo no crescimento e esporulação do fungo Beauveria bassiana (Bals.) Vuill. Anais da Sociedade Entomológica do Brasil , v.8, p.203-206, 1979.

ALVES, S. B.; MORAES, S.A. Influência da luz sobre o crescimento e esporulação de Beauveria bassiana (Bals.) Vuill, Ecossistema, v.4, p.43-50, 1979.

ALVES, S.B.; FORTI, L.C.; CIVIDANES, F.J. Influence of light color on some biological activities Metarhizium anisopliae (Metsch) Sorok. an entomopathogenic fungus. Revista Brasileira de Entomologia, v.24, p.123-125, 1980.

AZEVEDO, J.L. Controle microbiano de insetos pragas e seu melhoramento genético. In: MELO, I.S.; AZEVEDO, J.L.(Ed.) Controle biológico I. Jaguariúna: Embrapa Meio Ambiente, 1998a. p.69-96.

AZEVEDO, J.L. Genética de microrganismos. Goiânia: Editora da Universidade de Goiás, 1998b. 478p.

AZEVEDO, J.L.; COSTA, S.O.P. Exercícios práticos de genética. São Paulo: Cia Ed. Nacional; EDUSP, 1973. 288p.

AZEVEDO, J.L.; MESSIAS, C.L.; SILVEIRA, W.D. Genetics and breeding of the entomopathogenic fungus Metarhizium anisopliae: parasexuality and protoplast fusion. In: CROCOMO, O.; SHARP, J.; EVANS, W.R.; BRAVO, J.E. ; TAVARES, F.C.A.; PADDOCK, E.F. (Ed.) Biotechnology of plants and microorganisms. Columbus: Ohio State University Press, 1987. p.305-318.

BAGALHI, E.; VALADARES, M.C.C.; AZEVEDO, J.L. Parameiosis in the entomopathogenic fungus Metarhizium anisopliae. Revista Brasileira de Genética, v.14, p.261-271, 1991.

COCHRANE, V.W. Physiology of fungi. New York: John Wiley, 1997. 958p. 
COX, P.W.; THOMAS, C.R. Assessment of the activity of filamentous fungi using Mag fura. Mycological Research, v.103, p.757-763, 1999.

FRIGO, S.M.; AZEVEDO, J.L. Meios de cultura e produção de conídios em Metarhizium anisopliae (Metsch.) Sorokin. Anais da ESALQ, v.43, p.285-293, 1986.

GRIFFIN, D.H. Fungal fisiology. New York: Wiley-Liss, 1994. $605 p$.

INGLEBY, K.; MUNRO, R.C.; NOOR, M.; MASON, P.A.; CLEARWATER, M.J. Ectomycorrhizal populations and growth of Shorea parvifolia (Dipterocarpaceae) seedlings regenerating under three different forest canopies following logging. Elsevier Science, v.111, p.171-179, 1998.

INGLIS, G.D.; DUKE, G.M.; KAWCHUK, L.M.; GOETTEL, M.S. Influence of oscillating temperatures on the competitive infection and colonization of the migratory grasshopper by Beauveria bassiana and Metarhizium flavoviride. Biological Control, v.14, p.111-120, 1999.

KAVA-CORDEIRO, V.; LUNA-ALVES-LIMA, E.A.; AZEVEDO, J.L. Survival and mutant production induced by mutagenic agents in Metarhizium anisopliae. Scientia Agricola, v.52, p.548-554, 1995

LILLY, V.G.; BARNETT, H.L. Physiology of the fungi. New York: McGraw-Hill, 1951. 561p.

MAGALHÃES, B.P. Microbial control of grasshoppers in Brazil with the use of entomopathogenic fungi. In: MARTINS, M.T.; SATO, M.I.Z.; TIEDJE, J.M.; HAGLER, L.C.N.; DOBEREINER, J.; SANCHES, P.S. (Ed.) Progress in microbial ecology. Rio de Janeiro: Sociedade Brasileira de Microbiologia , 1997. p.429-433

MAGALHÃES, B.P.; FRAZÃO, H.D. Effects of temperature, water content and substrate on conidial production of Metarhizium flavoviride. Revista de Microbiologia, v.27, p.242-246, 1996.

MESSIAS, C.L. ; AZEVEDO, J.L. Parasexuality in the Deuteromycete Metarhizium anisopliae. Transactions of the British Mycological Society, v.75, p.473-477, 1980.
ONOFRE, S.B. Postura e eclosão de Boophilus microplus (Can., 1887) coletados na região Sudoeste do Paraná, sob condições controladas. In: JORNADA DE INICIAÇÃO CIENTÍFICA, 3., Pato Branco, 1998. Anais. Pato Branco: CEFET-PR, 1998. p.61-63.

ONOFRE, S.B.; MINIUK, C.M.; BARROS, N.M.; AZEVEDO, J.L. Pathogenicity of Metarhizium flavoviride var. flavoviride (Gams \& Rozyspal) and Metarhizium anisopliae var. anisopliae (Metsc.) Sorokin to the bovine tick Boophilus microplus (Can. 1887) The American Journal of Veterinary Research, 2001./ In Press/.

PONTECORVO, G.; ROPER, J.A.; HEMMONS, L.M.; MAC DONALD, K.D.; BUFTON, A. W. J. The genetics of Aspergillus nidulans. Advances in Genetics, v.5, p.141-238, 1953.

ROBERTS, D.W. The role of basic research on the development of fungi as bioinseticides. In: SIMPÓSIO DE CONTROLE BIOLÓGICO 5., Foz do Iguaçu, 1996. Anais. Foz do Iguaçu, 1996. p.108-116.

SOSA-GOMES, D.R.; ALVES, S.B. Caracterizacion de once aislamientos de Metarhizium anisopliae (. Metsch.) Sorok: I. Estandarizacion, virulencia y actividad enzimatica. CIRPON, Revista de Investigacion, v.1 p.83-102, 1983.

TULLOCH, M. The genus Metarhizium. Transactions of the British Mycological Society, v.66, p.407-411, 1976

VALE, T.L. Influência da qualidade da luz no crescimento e esporulação de Metarhizium anisopliae (Metsch.) Sorok. Piracicaba, 1983, 78p. Dissertação (Mestrado) - Escola Superior de Agricultura "Luiz de Queiroz", Universidade de São Paulo.

VICENTINI, S.; MAGALHÃES, B.P. Infection of the grasshoper, Rhammatocerus schistocercoides Rehn by entomopathogenic fungus, Metarhizium flavoviride Gams \& Rozsypal. Anais da Sociedade Entomológica do Brasil, v.25, p.309-314,1996.

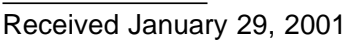

